Hankusz Éva

\title{
Határnevek összevető vizsgálata a szatmári térségben*
}

1. A helynévrendszerek területi differenciáltságának kérdésköre sokáig nem tartozott a névkutatás főbb vizsgálati tárgyai közé. Noha az egy-egy térség helynévrendszerének jellegzetességeit taglaló munkák szerzői rendszerint felhívták a figyelmet a más területek névanyagával való összevetés igényére (vö. HOFFMANN 1993b: 266), az ilyen jellegü vizsgálatok csak a közelmúltban kerültek előtérbe. DITRÓI ESZTER a helynévrendszerek területi eltéréseit, illetve az azt meghatározó nyelven kívüli tényezőket településenkénti összehasonlító elemzéssel vizsgálta. Munkájában a névrendszerek területi eltéréseit a földrajzi környezet, a migráció és az idegen nyelvi környezet hatásával magyarázta (2017). Hasonló jellegü vizsgálatokat magam is végeztem a szatmári térség névrendszerei körében egy-egy helynévfajtára koncentrálva. Elsőként az egykori Szatmár vármegye magyarországi és romániai részén fekvő, egymással szomszédos területek folyóvízneveinek összevető elemzését végeztem el (HANKUSZ 2019a), majd a területi eltéréseket a határnevek vonatkozásában vizsgáltam 6 magyarországi és 3 romániai település bevonásával (HANKUSZ 2019b). Jelen írásom ez utóbbi vizsgálathoz igen szorosan kapcsolódik, ugyanis a határnevek összevető elemzését egy nagyobb területre igyekszem kiterjeszteni, ami a korábbi vizsgálati eredmények érvényességének igazolása mellett új összefüggések feltárásához is vezethet. A vizsgálatba bevont 57 település egy tömbben helyezkedik el, három ország (Magyarország, Románia és Ukrajna) területét érintve. A magyarországi területről 24 település határneveit dolgoztam fel KÁLNÁSI ÁRPÁD és SEBESTYÉN ÁRPÁD gyüjtésére támaszkodva (1993). A határ romániai oldaláról 21 település névanyagát vontam vizsgálat alá, ehhez a BURA LÁSZLÓ kötete (2008) mellett az általam végzett kiegészítő helynévgyüjtésből származó névadatokat, illetve további, egy-egy település helyneveit közreadó munkákat is felhasználtam (KISS K. 2004, 2014, SZILÁGYI-VARGA 2015). A 12 ukrajnai település esetében pedig a KOCÁN BÉLA által gyüjtött helynévanyagra támaszkodtam (2003; emellett Batár, Csepe, Fertősalmás, Forgolány, Nagypalád, Tiszabökény és Tiszaújlak helyneveit a szerző még

\footnotetext{
* A tanulmány az NKFI 128270. számú pályázata és az Innovációs és Technológiai Minisztérium ÚNKP-20-3-II kódszámú Új Nemzeti Kiválóság Programjának a Nemzeti Kutatási, Fejlesztési és Innovációs Alapból finanszírozott szakmai támogatásával készült.
} 
ezidáig nem publikálta), illetve Szőlősgyula helyneveit BARTA VIKTÓRIA gyüjtése nyomán dolgoztam fel (2009: 213-224).

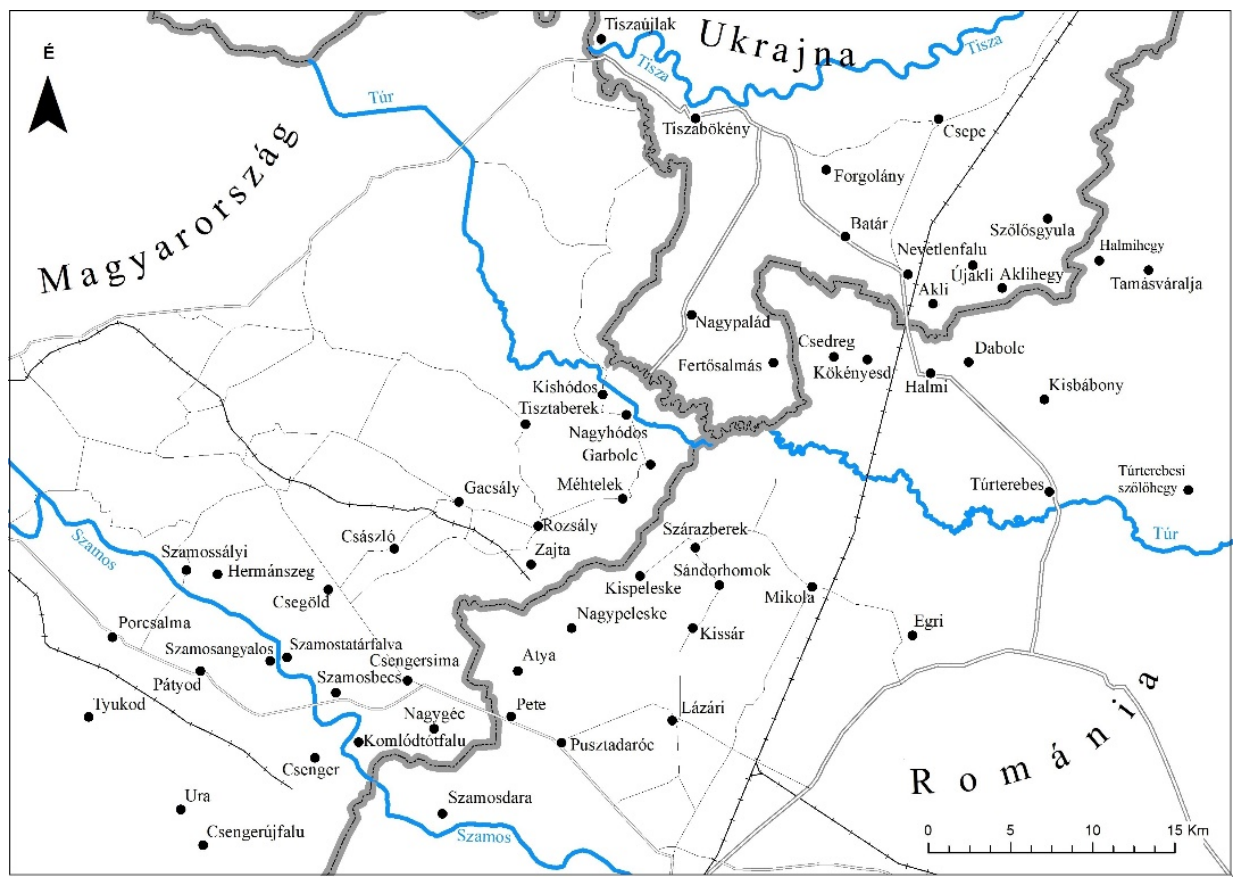

1. ábra. A vizsgált települések

A vizsgálatba vont térségek névrendszereinek összevető elemzése kiváló lehetőséget biztosít a trianoni békeszerződés nyomán meghúzott országhatároknak a helynévrendszerek alakulásában betöltött szerepének vizsgálatára. E tényező kapcsán bizonyára nem megalapozatlan az a feltételezés, hogy a hosszú ideig fennálló megosztottság, akárcsak a nyelvben általában, a helynévrendszerekben is az elkülönülést erösítette.

Az alábbiakban tehát a magyarországi, romániai és ukrajnai települések határneveinek funkcionális-szemantikai, illetve lexikális-morfológiai síkon mutatkozó eltéréseit vizsgálom. Az analízishez a HOFFMANN ISTVÁN által kidolgozott helynévelemzési modellt veszem alapul (1993).

2. A névrendszerek összevetésének első lépéseként az egy- és kétrészes helynévstruktúrák megoszlását tekintem át a vizsgált térségekben (lásd a 2. ábrát).

\begin{tabular}{|l|c|c|c|}
\hline & egyrészes nevek & kétrészes nevek & összesen \\
\hline magyarországi terület & $26,2 \%$ & $73,8 \%$ & 3067 \\
\hline romániai terület & $40,6 \%$ & $59,4 \%$ & 1630 \\
\hline ukrajnai terület & $41,0 \%$ & $59,0 \%$ & 456 \\
\hline
\end{tabular}

2. ábra. Az egy-és kétrészes nevek aránya a vizsgált térségekben 
Az adatok azt mutatják, hogy noha mindhárom térségben a kétrészes nevek dominanciája jellemző, ezeknek a szerkezeteknek a túlsúlya a magyarországi területen a legszembetűnőbb. Ott a névállománynak mintegy háromnegyedét teszik ki, míg a határon túli térségekben a neveknek alig több mint fele sorolható ide. Az egyrészes neveknek a nyelvterület keleti területein jellemző nagyobb gyakoriságára DITRÓI ESZTER is felhívta a figyelmet a Veszprémi járás, a Fehérgyarmati járás és a csíki térség helyneveinek vizsgálatakor (2017: 46). DITRÓI azonban ezt a tendenciát egymástól több száz kilométerre fekvő települések összevetése révén mutatta ki, az általam vizsgált névanyag azonban arról tanúskodik, hogy mindez kisebb léptékben is érvényesülhet, ami talán nem független a névminták terjedésének gátat szabó száz éves országhatár jelenlététől.

A szatmári térség határnevei körében az egyrészes nevek gyakoriságát az alábbi térkép településekre lebontva szemlélteti (lásd a 3. ábrát). (A százalékos gyakoriságok meghatározásánál mindig az adott település vagy térség teljes határnévállományát tekintem $100 \%$-nak.)

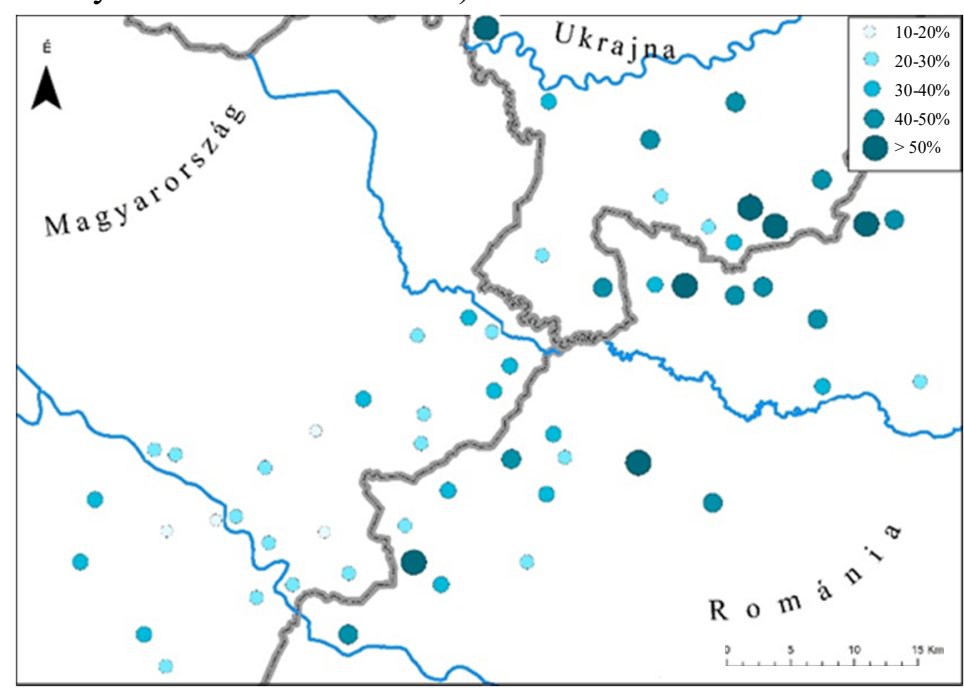

3. ábra. Az egyrészes nevek megoszlása a vizsgált térségekben

A térkép tanúsága szerint az egyrészes nevek a határon túli térségekben igen jellemző névtípusnak mondhatók. Míg a magyarországi területen az egyrészes nevek aránya egyetlen település esetében sem haladja meg a 30\%-ot, a határon túli területeken kiugró értékekkel is szép számban találkozunk. Az egyrészes nevek dominanciája fóként az ukrán-román határ mentén fekvő települések esetében rajzolódik ki: a romániai területen Mikola, Kökényesd és Halmihegy emelhető ki, ahol a határnevek több mint fele egyrészes, sőt ez utóbbi esetében ez az arány $76 \%$. Hasonlóan magas értéket mérhetünk az ukrajnai területen Aklihegy és Újakli esetében, ahol a határnevek 78\%-a egyrészes struktúrával rendelkezik, Tiszaújlak és Csepe határnevei körében is az egyrészes nevek túlsúlya jellemző. 
Az egy- és kétrészes névszerkezetek a bennük kifejeződő szemantikai tartalom alapján további altípusokra oszthatók. Beszélhetünk fajtajelölő (F), sajátosságot kifejező (S), illetve megnevező (M) névrészfunkciókról. Az egyrészes helynevekben bármely funkció megjelenhet, a kétrészes nevek esetében pedig a névrészfunkciók háromféle kombinációja lehetséges: $\mathrm{S}+\mathrm{F}$ (Tölgyes-szeg), $\mathrm{S}+\mathrm{M}$ (KisÁrcius) és M+F (Pinkác-cser) (vö. HOFFMANN 1993: 53-54). Ezeknek a struktúráknak a megoszlását mutatják be a vizsgált térségekben a 4. ábra diagramjai.

magyarországi terület
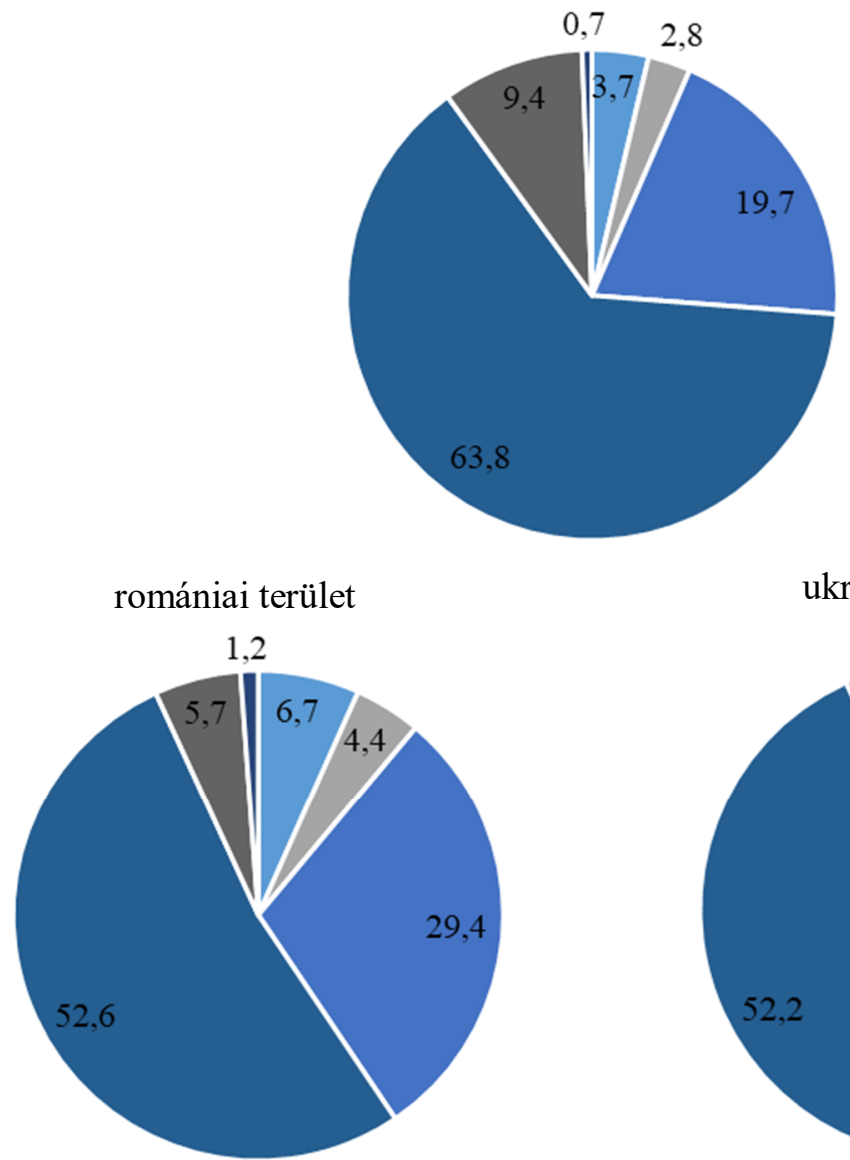

ukrajnai terület

$\|\mathrm{F}=\mathrm{M}\| \mathrm{S}=\mathrm{S}+\mathrm{F}\|\mathrm{S}+\mathrm{M}\| \mathrm{M}+\mathrm{F}$

4. ábra. A szemantikai szerkezetek megoszlása a vizsgált térségekben

A szemantikai szerkezetek megoszlása a határon túli térségek esetében hasonlónak mondható, míg a magyarországi területen nagyobb eltérésekkel számolhatunk. Itt az egyrészes nevek mindhárom típusa ritkábban fordul elö, mint a romániai és ukrajnai területen, de legnagyobb eltérés az $\mathrm{S}$ funkció gyakoriságában 
mutatkozik: ez a struktúra ugyanis mintegy 10\%-kal nagyobb arányban fordul elő a határon túli területeken. A kétrészes nevek közül az S+F szemantikai struktúra mutatkozik messze a legjellemzőbb szerkezetnek, az $\mathrm{S}+\mathrm{M}$, illetve $\mathrm{M}+\mathrm{F}$ szerkezetek aránya meglehetősen alacsony mindhárom térségben.

3. A névrendszerek eltérései mind a funkcionális-szemantikai, mind pedig a lexikális-morfológiai szerkezetek terén megnyilvánulhatnak, így az alábbiakban ilyen szempontok szerint tanulmányozom a három ország vizsgálat alá vont településeinek határneveit.

3.1. A fajtajelölő funkció mind az egy-, mind pedig a kétrészes nevek esetében kiemelt jelentőséggel bír, ez a névfunkció ugyanis valamennyi vizsgált térségben a határnevek csaknem kétharmadában jelen van. A hely fajtájának megjelölésére a földrajzi köznevek alkalmasak (HoFFMANN 1993: 47). A földrajzi köznévi lexémát tartalmazó egy- és kétrészes nevek térségenkénti arányát az 5. ábra mutatja.

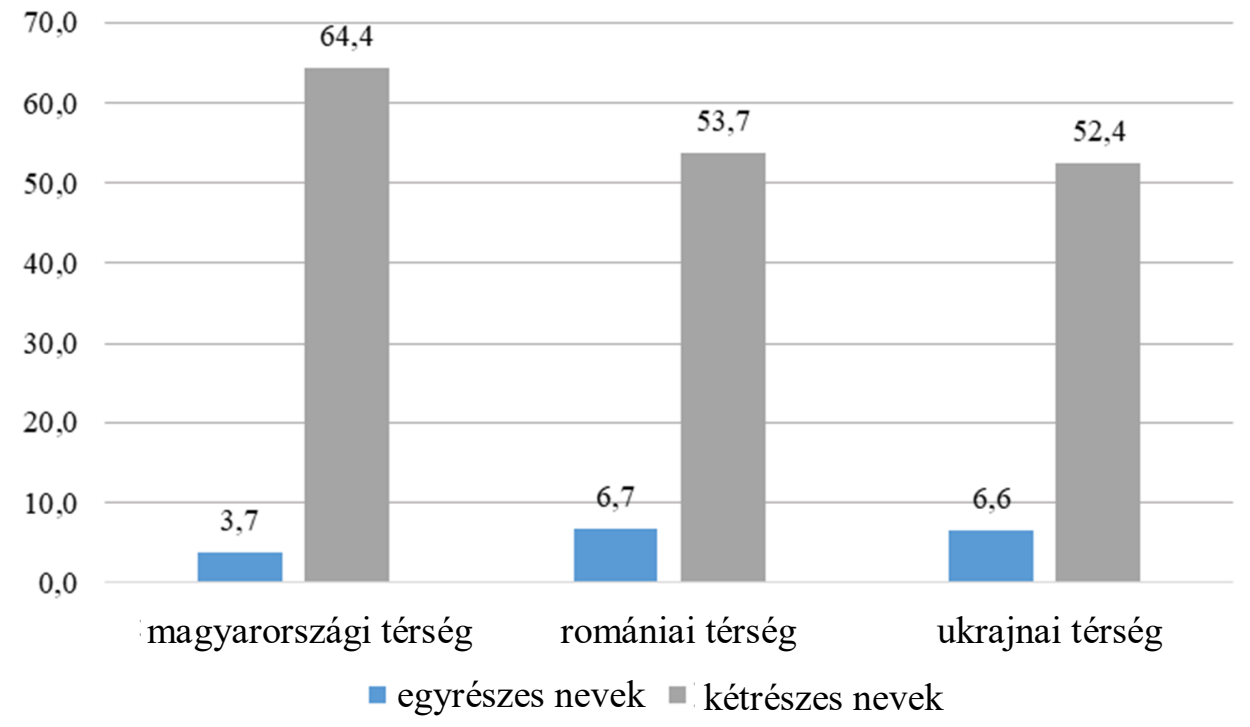

5. ábra. A földrajzi köznevet tartalmazó egy-és kétrészes nevek térségenkénti aránya

A határon túli térségekben mind az egy-, mind pedig a kétrészes, földrajzi köznevet tartalmazó nevek aránya közel azonos, 6, illetve 53\% körüli értéken áll. A magyarországi területen azonban az egyrészes fajtajelölő határnevek aránya alig több, mint a fele $(3,7 \%)$ a romániai és az ukrajnai területen mért arányoknak. Az ide sorolható kétrészes nevek esetében ugyanakkor fordított a helyzet, hiszen a földrajzi köznévi utótagú kétrészes nevek aránya a magyarországi területen mintegy 10\%-kal meghaladja a határon túli térségekben kapott értékeket.

A fenti arányokat az is befolyásolja, hogy a Disznólegelö, Ökörlegelő típusú neveket egy- vagy kétrészes struktúraként értelmezzük-e. Amennyiben ezeket 
összetett földrajzi köznévből alakult nevekként értékeljük, úgy ezek az egyrészes F funkciójú nevek csoportját gyarapítják. Kétséges azonban, hogy az ilyen elnevezések valóban egyrészes neveknek tekintendők-e. HOFFMANN ISTVÁN a Helynevek nyelvi elemzése címủ munkájában a jelentéshasadással keletkezett nevek között tárgyalja ezt a szócsoportot kiemelve, hogy speciálisabb jelentésük miatt válnak alkalmassá a tulajdonnévi szerepre. Megjegyzi azonban azt is, hogy a névtudat ezeket kétrészes névnek érzékeli (1993: 96). Póczos RITA az ide sorolható névadatokat a nyelvi környezetüket figyelembe véve vizsgálta, a kapott eredmények pedig többnyire a kétrészesség mellett szóltak: ezeknek a helyneveknek gyakran olyan szinonimáik vannak, melyekkel utótagjukban megegyeznek, elötagjuk viszont a helynek egy más sajátosságát fejezik ki: pl. Vásár/tér $\sim$ Kocsmai/tér (2010: 59). ${ }^{1}$ Erre a jelenségre az általam vizsgált névanyag is számos példát szolgáltat: pl. Disznó/legelö Kis/legelö (Pátyod), Ökör/legelö Báró-tagosi/legelö (Szamosangyalos), Epres/kert Cigány/kert (Kisbábony). Ugyanakkor szót kell ejtenünk a Dögtér, Hullámtér típusú nevekről is. Ezek esetében az általam vizsgált névanyagot tekintve nem jellemző az előtagjukban eltérő szinonimák előfordulása, ami bizonyára azzal is összefügg, hogy a tér utótag a határnevekben nem tekinthető olyan tipikus helynévformánsnak, mint a fent említett legelö és kert földrajzi köznevek. Ezeknek a neveknek a kétrészes szerkezetekként való elemzése mellett szól azonban az a körülmény, hogy — ha elötagjukban nem is, de — utótagjukban különböző szinonimák ezek esetében is előfordulhatnak: a Dögtér szinonimájaként például megjelenik helyenként a Dögtemető névalak, illetve a Hullámtér szinonim párjaként a Hullám alak is előfordul egy ízben. Mindezek fényében az általam vizsgált térségek ilyen típusú neveit az elemzések során egységesen kétrészes $\mathrm{S}+\mathrm{F}$ szerkezetủ neveknek tekintem.

3.2. Az egyrészes, földrajzi köznévvel azonos helynevek közül mindhárom térségben a Legelö névforma fordul elő leggyakrabban, de kiemelhetők még a Forduló, Rét, Rekesz 'terület, amelyet sövénnyel vagy árokkal vettek körül' (FKnT. 274) (magyarországi terület); a Liget, Rét, Láz 'erdei tisztás, irtás' (FKnT. 226) (romániai terület); illetve az Erdö, Irtás (ukrajnai terület) földrajzi köznévi elnevezések is. Noha a használatban lévő földrajzi köznévvel azonos alakú helynevek a három térségben hasonló képet mutatnak, akadnak olyanok, melyek csak egy-egy térség névanyagában szerepelnek. Csak a magyarországi területen jelenik meg a Palaj 'folyó homokos, lapos partja' (FKnT. 260), a Rekesz és a Fenék 'valamely terület mélyebben fekvő része' (FKnT. 143). A romániai területen a Lazna 'gazos hely' (ÚMTsz.) és a Fertő' 'mocsaras terület időnként vízzel újra megtelő tócsákkal' (FKnT. 145), az ukrajnai területen pedig a Gyepü 'felszántatlan

\footnotetext{
${ }^{1}$ Itt és a továbbiakban — ahol szükségesnek tartom a struktúra jelzését — a névrészeket / jellel, a névelemeket pedig lexémák esetén + jellel, toldalékmorfémák esetén pedig - jellel különítem el.
} 
gyepszalag' (FKnT. 166) és a Vápa 'vizenyős, mocsaras terület' (FKnT. 326) említhetők meg, mint területi jellegzetességek. ${ }^{2}$

Földrajzi köznevek tipikusan kétrészes nevek utótagjaként jelentkeznek. Ilyen szerepben mindhárom térségben a tag 'a tagosított, müvelés alatt lévő határ egyben lévő darabja' (FKnT. 305) a leggyakrabban használt földrajzi köznév. A magyarországi területen a határnevek 14,4 százalékában jelenik meg utótagként ez a lexéma. Hasonló érték jellemző az ukrajnai térségben, ott ez az arány 13,4\%, a romániai területen viszont nagyjából feleakkora, mindössze 6,9\%-os átlagérték jellemző. A tag földrajzi köznévi utótag előfordulásának gyakoriságát ugyanakkor érdemes településenként is megvizsgálni (lásd a 6. ábrát).

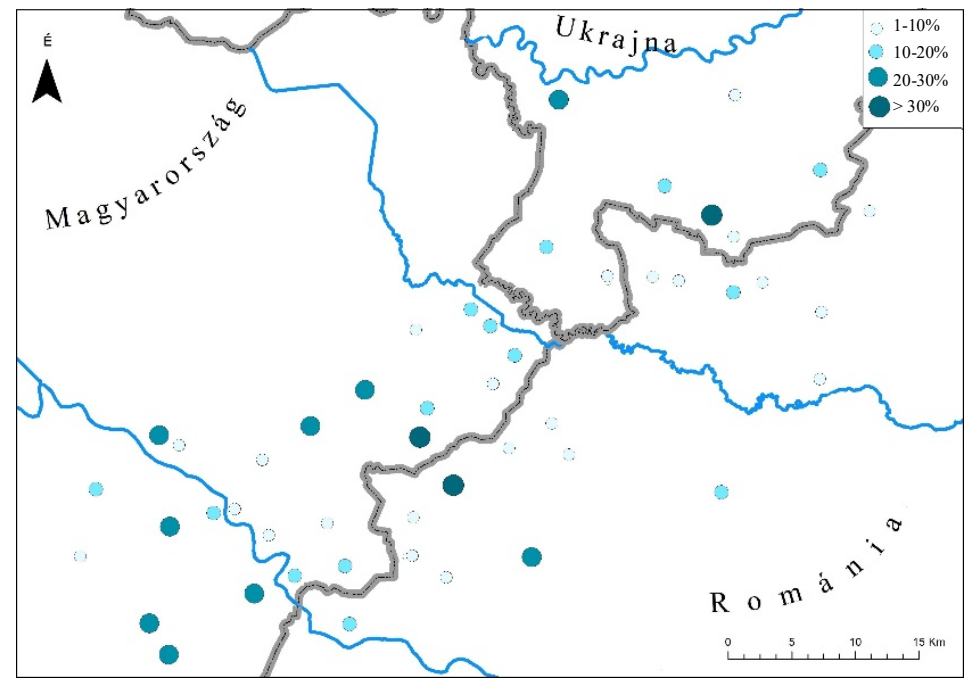

6. ábra. $A$ tag földrajzi köznévi utótag a vizsgált térség határneveiben

Noha a fent említett átlagértékek azt jelzik, hogy az ukrajnai és a magyarországi területen a tag lexéma előfordulási gyakorisága közel azonos, a térképen jól látható, hogy az ukrajnai települések mutatói sokkal inkább a romániai viszonyokkal rokoníthatók. Az ukrajnai térség viszonylag magas átlagértéke a Nevetlenfalu és Tiszabökény esetében jellemző magas mutatókkal magyarázható: előbbi esetében $42 \%$-os, utóbbinál pedig $25 \%$-os gyakorisággal jelenik meg ez a lexéma. A térség többi településén azonban minden esetben $20 \%$ alatt marad ez

\footnotetext{
${ }^{2}$ Egyebek mellett a palaj, fertő és vápa földrajzi köznevet tartalmazó helynevek esetében bizonytalan lehet, hogy vizsgálhatók-e ezek a határnevekkel együtt, hiszen a HoFFMANN-féle tipológia értelmében sokkal inkább a vízparti helyek elnevezéseinek sorába illeszkednek. Mivel az általam vizsgált területet a Szamos és a Túr is átszeli, ilyen típusú nevek nagy számban előfordulnak. Mára azonban ezek jobbára megmüvelt területeket jelölnek, így a névhasználók körében jelentésük is megváltozott. Ennek fényében célszerünek látom az elemzésüket a határnevek körében elvégezni.
} 
az arány, sőt a vizsgált falvak közül négyben egyáltalán nem fordul elő a tag földrajzi köznév. Hasonló a helyzet a romániai oldalon is, ott a települések háromnegyedében $10 \%$ alatti a névelem jelenléte (sőt köztük négyben teljesen hiányzik). Kiugróan magas érték mindössze Nagypeleske (47\%) és Lázári (22\%) esetében mutatkozik. Meg kell azonban jegyeznünk, hogy ezekben a falvakban igen alacsony a határnevek száma, így ezek az arányok mindössze 9 , illetve 11 névadatot takarnak. A tag földrajzi köznevet tartalmazó kétrészes nevek 92\%-ának előtagja a hely birtokosát vagy használóját jelöli meg, így a névrész gyakoriságában mutatkozó területi eltérések bizonyosan összefüggnek a birtoklás kifejezésére használt névminták különbségeivel.

A tag mellett az öt leggyakrabban használt földrajzi köznév között szerepel mindhárom térségben a legelö és a kert utótag. A magyarországi területről kiemelhetjük még a tábla, föld és dülö, a romániai térségböl az erdö, föld és tábla, az ukrajnai területről pedig az erdő, alj és láz földrajzi közneveket. Noha világosan látszik, hogy az utótagként leggyakrabban megjelenő földrajzi köznevek között a vizsgált térségekben gyakoriak az átfedések, néhány területi eltérésre is érdemes rámutatnunk. A magyarországi települések esetében a dülő földrajzi köznév a határneveknek mintegy 3\%-ában fordul elő utótagként, míg a romániai területen ez az arány mindössze $0,5 \%$, az ukrajnai falvakban pedig egyetlen határnévben sem jelenik meg ez a lexéma. Még érzékletesebb a különbség, ha az arányok mellett a nevek számára is utalunk: míg a magyarországi területen 88 , a romániai területen mindössze 8 névben szerepel utótagként a dülő földrajzi köznév. Ezzel épp ellentétes helyzet mutatkozik a láz 'erdei tisztás, irtás' földrajzi köznév térségenkénti felhasználtságában. A romániai és ukrajnai területen 2,5\%os, illetve $2 \%$-os gyakorisággal jelenik meg ez a lexéma, ezzel szemben a magyarországi területen mindössze 3 névben fordul elö, ami a határneveknek alig 0,1\%-át teszi ki.

4. A megnevező funkció mind az egy-, mind pedig a kétrészes nevek körében periférikus helyzetben van valamennyi vizsgált térség névrendszerében. A névfunkció gyakorisága azonban vidékenként kisebb eltérést mutat. Az egyrészes M funkciójú nevek az ukrajnai térségben jelentkeznek legnagyobb arányban, ott a határnevek 6,4\%-át teszik ki, a romániai területen ennél kisebb, 4,4\%-os arány jellemző, a magyarországi területen pedig mindössze a nevek 2,8\%-a M funkciójú. Fordított a helyzet a kétrészes $\mathrm{S}+\mathrm{M}$ szerkezettel leírható nevek esetében: ezek aránya ugyanis a magyarországi területen a legnagyobb, a határnevek közel 10\%át teszik ki, míg a határon túli területeken e névszerkezet aránya $6 \%$ körül mozog. Ez azt jelzi, hogy a helynevek differenciálása, azaz egy adott nevet viselö terület kisebb egységeinek az alapnév felhasználásával történő másodlagos megnevezése a magyarországi térségben jóval gyakoribb. Újabb területi eltéréseket figyelhetünk meg akkor, ha azt is vizsgáljuk, hogy az M funkciójú névrészhez kapcsolódó sajátosságjelölő előtag a helynek milyen tulajdonságát jelöli meg (lásd a 7. ábrát). 


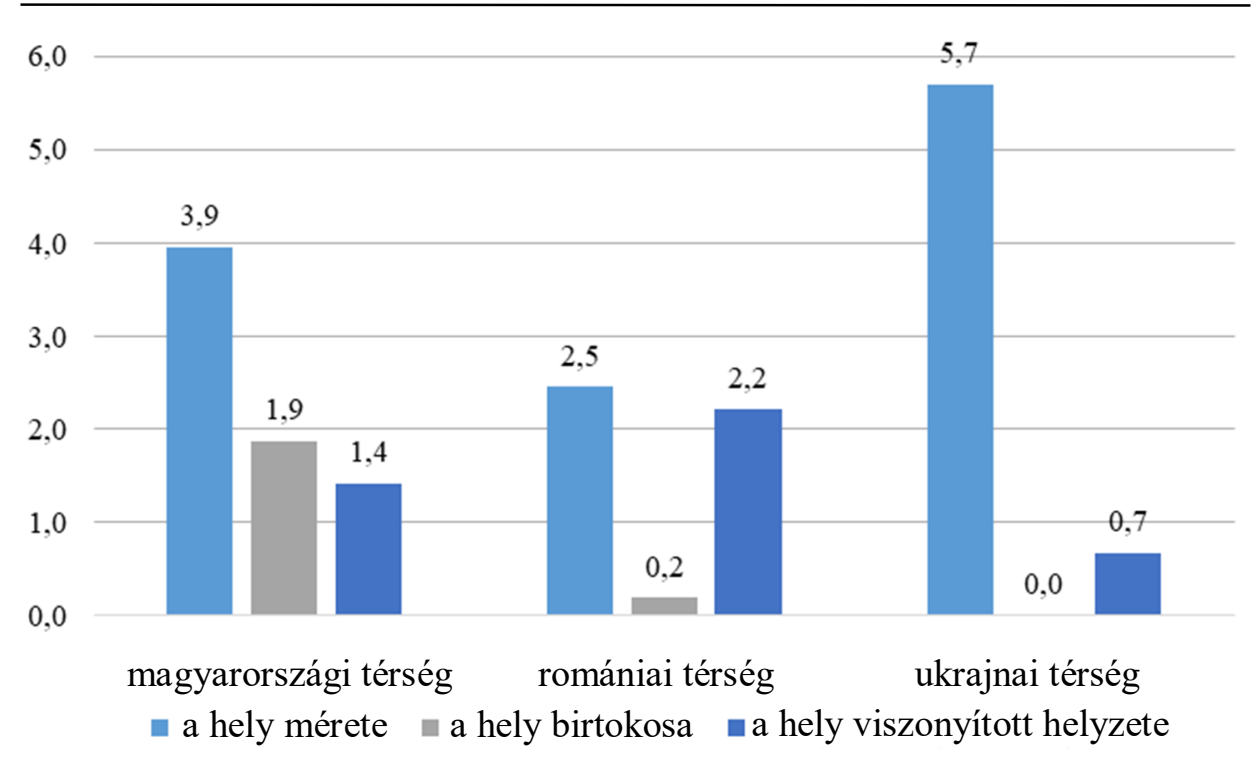

7. ábra. A megnevezö funkciójú utótaghoz kapcsolódó sajátosságjelölö névrészek szemantikai megoszlása

Megnevező funkcióban álló névrészekhez tipikusan a hely méretére utaló sajátosságjelölő előtag kapcsolódik mindhárom térségben. Olyan nevek tartoznak ide, mint a Kis-Kerek-szeg, Nagy-Kerek-szeg, Kis-Banké, Nagy-Banké, Kis-Csókás, Nagy-Csókás stb. Ugyancsak jellemzőnek mondható a hely viszonyított helyzetének megjelölése az S funkciójú előtagban. Ide sorolhatók a következő nevek: $A l$ só-Német-tag, Felsö-Német-tag, Külsö-Barackos, Belsö-Barackos, Belsö-Vargaláz, Külsö-Varga-láz stb. Az említett szemantikai típusok a romániai területen hasonló arányban jelennek meg, ezzel szemben a magyarországi és ukrajnai területen a hely relatív helyzetét megjelölő nevek aránya jócskán elmarad a hely méretére utaló nevek mutatóitól. Még inkább szembeötlő eltérés, hogy míg a határon túli térségekben más szemantikai csoport csak elvétve fordul elő az itt vizsgált névtípus előtagjaként, addig a magyarországi területen tekintélyes számban jelennek meg a hely birtokosát kifejező előtagok (pl. Madarassy-féle-Kis-erdö, Kürthy-Kenderátó, Szuhányi-Kis-tag, Báró Nagy-legelöje, Györy Endre-féle-Hosszúerdö, Sinkó Terca-féle-Mocsolya, Balogh-Vágás stb.). Ebben a térségben kisebb számban ugyan, de más szemantikai jegyek is felbukkannak az ide sorolt nevek előtagjában. Kifejeződhet a hely alakja (Görbe-Szepszes), hömérséklete (HüvösÉgeralja), kora (Új-Péchy-tag), használója (Pap Nyilasa), tájrész vagy település közelében való fekvése (Pocvégesi-Kertalja, Angyalosi-Izgét) stb. A romániai és föként az ukrajnai névanyagban ilyen névtípusokkal csak elvétve találkozhatunk.

Helynévi lexémák a megnevező funkció mellett megjelennek lokális viszonyt jelölő S funkciójú névrészekben is. Az ide sorolható nevek a határon túli térségek 
névállományában közel azonos arányban fordulnak elő. A romániai területen $11 \%$, az ukrajnai térségben pedig $10,7 \%$ a lokális viszonyt jelölő helynévi névrészek gyakorisága. A magyarországi településeket tekintve ennél nagyobb, 16,3\%os arány mutatkozik.

Azon túl, hogy a magyarországi területen gyakrabban jelennek meg helynévi lexémák sajátosságjelölő funkcióban, az ilyen szerepben álló helynevek típusait tekintve is változatosabb képet mutat ez a térség (lásd a 8 . ábrát). Noha mindhárom területen a kétrészes nevek vesznek részt leggyakrabban új nevek alkotásában (Kis-erdö-láb, Póka-telek alja, Nagy-erdö-dülö), a magyarországi névanyagban az egyrészes helynevek (Galambos alja, Cselösz-oldal, Turc-láz), illetve a képzővel ellátott egy- és kétrészes helynévi struktúrák (Csengeri-dülö, Majoritag, Pap-erdei-tábla, Gémes-tói-rét) aránya sem mutat lényeges lemaradást. Ezzel szemben a határon túli térségekben ez utóbbi struktúrák jóval ritkábban jelennek meg új helynevekben.

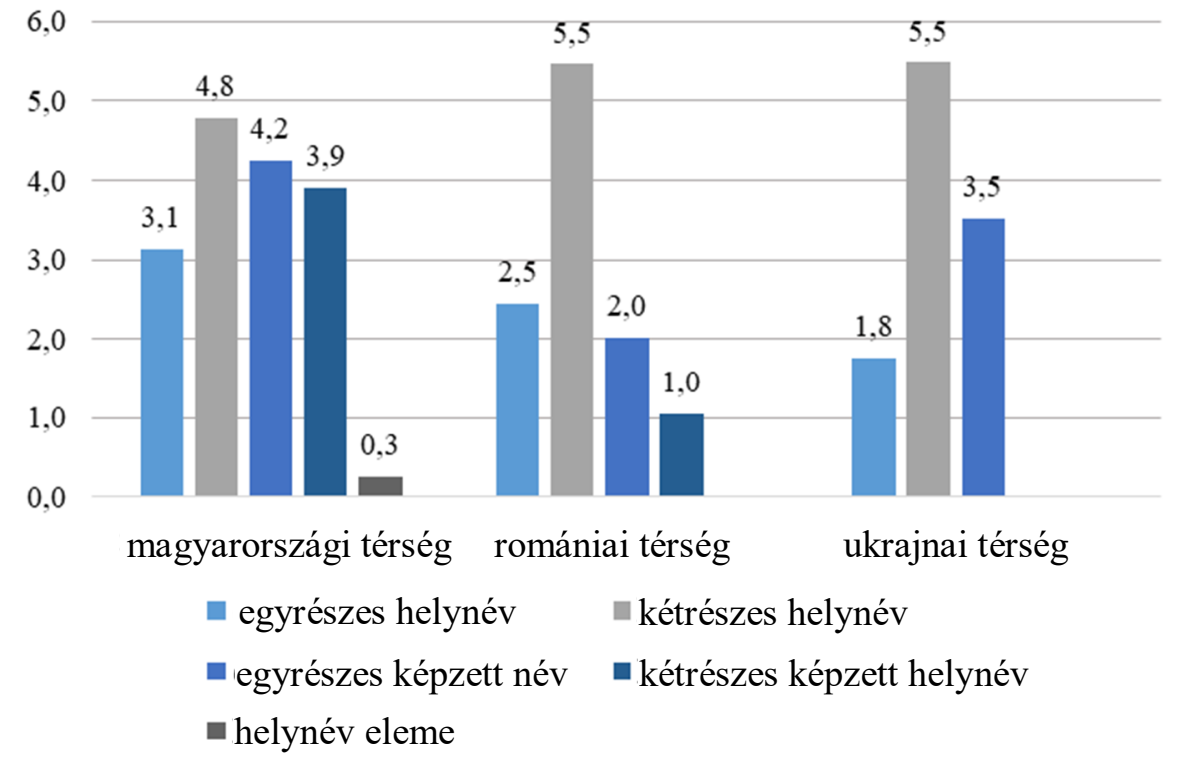
8. ábra. Az S funkcióban megjelenö helynévi névrészek elöfordulása a vizsgált térségekben

5. A vizsgált névállományokban a legjelentősebb funkcionális csoportot a sajátosságjelölő névrészek alkotják. Ez a névfunkció az egyrészes nevek között is szép számban megjelenik. A hely sajátosságára utaló névrészek között különbséget kell tennünk aszerint, hogy a helynek mely sajátossága fejeződik ki benne. A 9. ábra diagramja a sajátosságfunkció belső megoszlását mutatja az egyrészes nevek körében. 


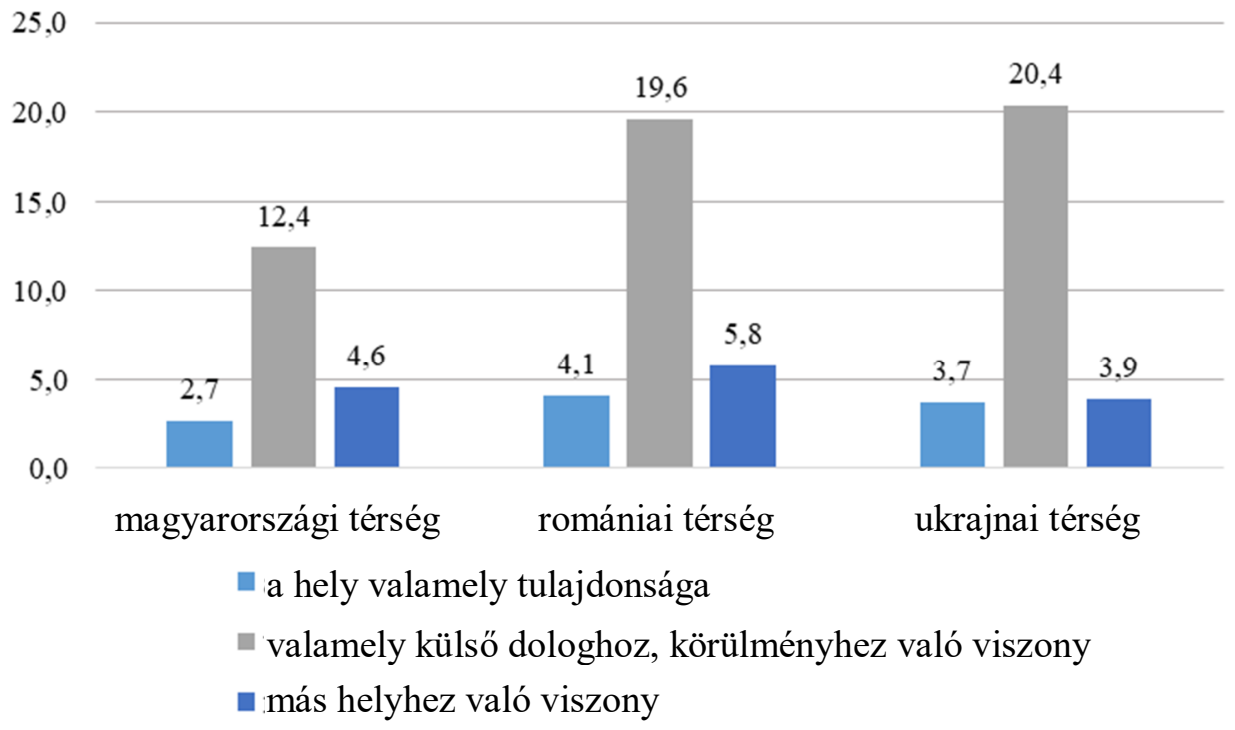

9. ábra. A sajátosságjelölő névrészek szemantikai megoszlása az egyrészes nevekben

5.1. A hely sajátosságára utaló egyrészes nevek között a külső dologhoz, körülményhez való viszonyt kifejező nevek alkotják a legnépesebb csoportot. A határon túli területeken az ide tartozó nevek aránya $20 \%$ körül mozog. Jóval alacsonyabb értéket láthatunk a magyarországi térségben, ahol ez az arány $12,4 \%$. Az itt mutatkozó eltérések jobb megvilágítása érdekében célszerủ az említett szemantikai csoport belső megoszlását is áttekinteni (lásd a 10. ábrát).

14,0

12,3

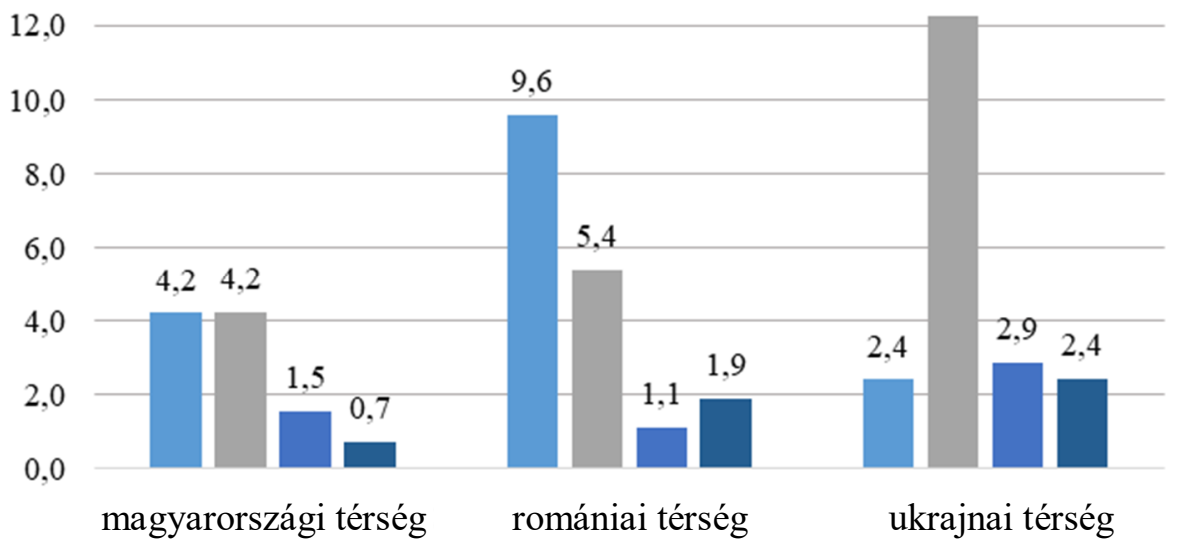

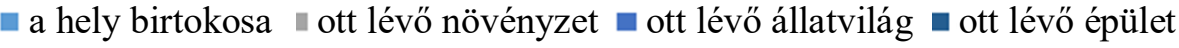

10. ábra. A helynek a külső dologhoz való viszonyát kifejezö névrészek leggyakoribb típusai az egyrészes nevekben 
A diagramból jól kivehető, hogy az eltérések hátterében többek között a birtoklás kifejezésére használt eltérő névminták állnak. Noha a hely birtokosának megjelölése tipikusan kétrészes helynévstruktúrákkal történik, a romániai térségben igen gyakoriak az egyrészes birtokosra utaló nevek, ott a határnevek 9,6\%-a sorolható ide. Ezzel szemben a magyarországi és ukrajnai területen a névhasználók jóval ritkábban használnak egyrészes struktúrát a birtoklás megjelölésére. Ezeken a területeken a határneveknek mindössze a 4,2\%-át, illetve 2,4\%-át teszi ki ez a névtípus. A területi eltérések pontosabb megvilágítása érdekében azonban az átlagértékek mellett érdemes a névtípus előfordulását településenként is megvizsgálni (ezt látjuk a 11. ábrán). A térképen jól kirajzolódik, hogy a birtokosra utaló egyrészes nevek használatának gócpontja a romániai térség északi, határ menti területe. A 20\%-os gyakoriságot meghaladó települések közül Mikolát és Halmihegyet érdemes kiemelni, ezek névállományában ugyanis a névtípus elöfordulása eléri a 32\%-ot, illetve az 53\%-ot. A térség délebbre fekvő területein azonban igen kis mértékü a jelenléte, sőt olyan települések is akadnak, ahol egyáltalán nem fordul elö ilyen elnevezés.

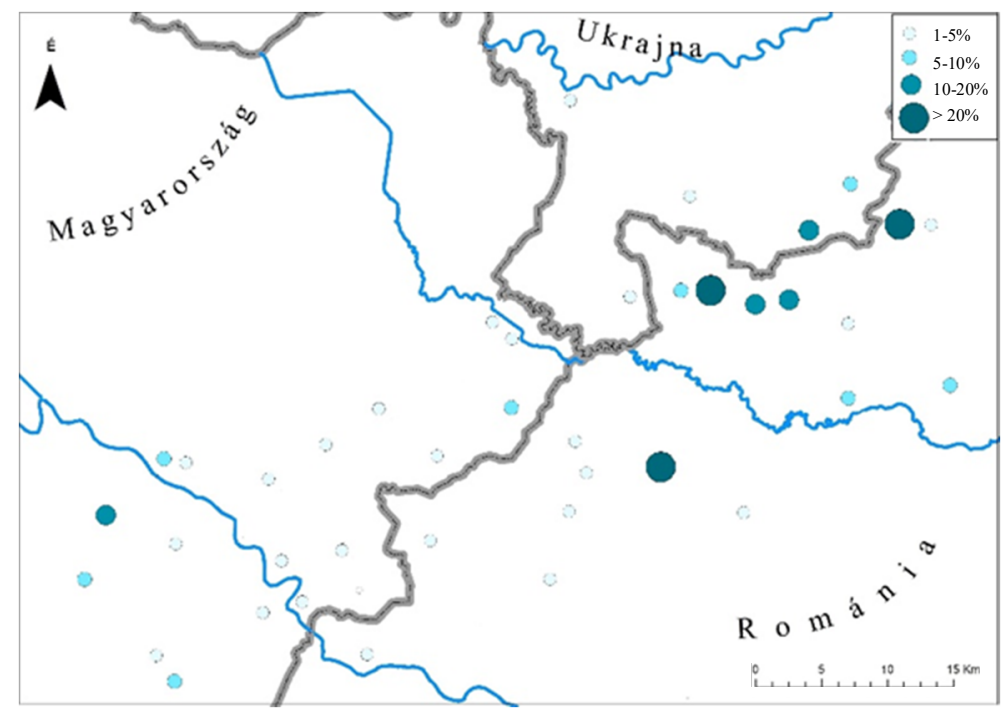

11. ábra. A birtokosra utaló egyrészes nevek megoszlása a vizsgált területen

Egyrészes nevek esetében a birtoklás kifejezése puszta személynév vagy személyt jelölő közszó felhasználásával történik (Balogh, Fóris), illetve jelölt szerkezetet is alkalmaznak erre a funkcióra, amit az -é birtokjeles forma képvisel (pl. Csajláé, Tobáké, Burjáké, Szemák Pistáé stb.). Ez utóbbi struktúra elterjedési területét szemlélteti a 12. ábra. 


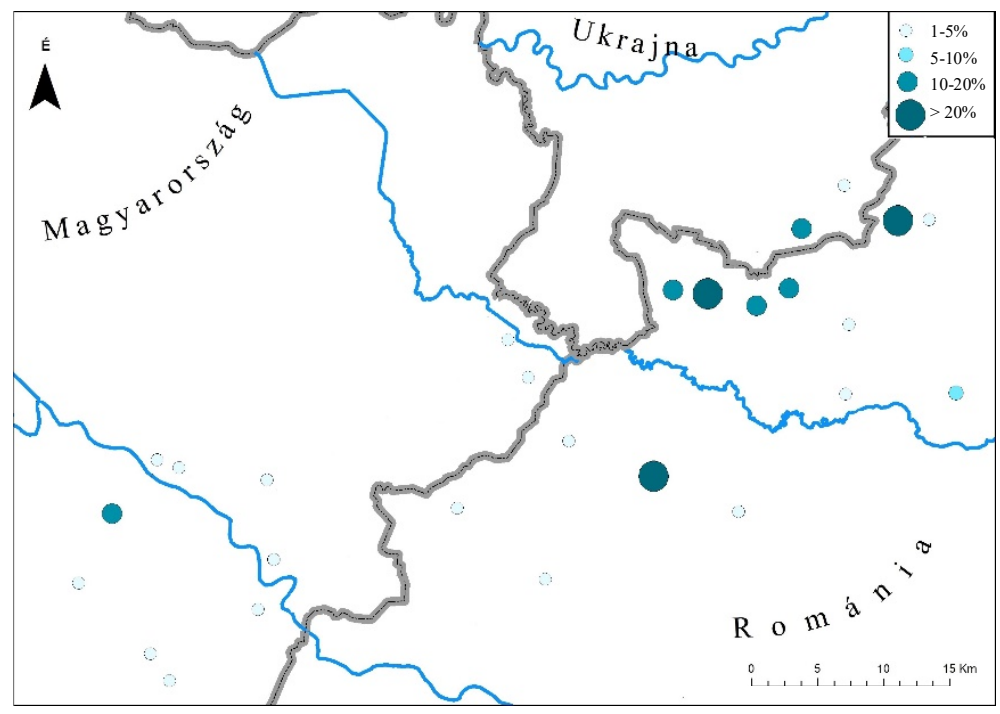

12. ábra. Az -é birtokjel használata a vizsgált területen

Az -é birtokjeles helynevek ugyancsak a romániai térség északi területén gyakoriak. A többi térségben feltünően kevés település névrendszerében használatos ez a névszerkezet: a magyarországi térségben inkább csak a Szamos menti települések névanyagában találkozunk kisebb arányban -é birtokjeles alakokkal, az ukrajnai térségnek pedig mindössze két településén adatolható ez a névtípus. Érdekes körülmény továbbá, hogy a magyarországi településeken az -é birtokjeles nevek szinonimájaként nagyon gyakran birtokos jelzős szerkezetek szerepelnek (pl. Csóké Csók-tag, Doktoré $\sim$ Doktor-tag, Jelesé Jeles-tábla, Groszmané Groszman-tag stb.). Ezzel szemben a romániai területen a legtöbb birtokjellel ellátott névnek nincs kétrészes szinonimája. Ez is azt mutatja, hogy az ilyen névalakok megjelenése a magyarországi területen inkább csak esetleges, míg a romániai térségben az -é birtokjel használata jellemző névalkotási modell.

$\mathrm{Az}$-é birtokjellel alakult neveknek a nyelvterület keleti részén való gyakoribb használatára HOFFMANN ISTVÁN is felhívta a figyelmet (1993: 85), illetve DITRÓ I ESZTER is hasonló következtetésre jutott a Veszprémi járás, a Fehérgyarmati járás és a csíki térség névrendszereinek összevető vizsgálata során: a tárgyalt toldalékelem szinte kizárólag a csíki térségben volt jellemző (2017: 59). Az általam vizsgált szatmári térség adatai részben megfelelnek ennek a tendenciának, azonban az is világosan látszik, hogy a névelem gyakoriságának növekedése a keleti területek felé haladva semmiképpen sem folyamatos, a névelem használata sokkal inkább egy-egy kisebb térség (a romániai terület északi része és a magyarországi Szamos menti terület) köré összpontosul.

A hely birtokosát megjelölő egyrészes nevek tárgyalásakor nem mehetünk el szó nélkül egy a magyarországi területen jelentkező sajátos névtípus mellett. 
Ezekben a nevekben a személynévhez vagy személyt jelölő közszóhoz a -féle névelem kapcsolódik: Mátyás-féle, Szabó Károly-féle, Szaplonczayné-féle, Egyház-féle stb. HOFFMANN ISTVÁN is említést tesz hasonló szerkezetü nevekről, s úgy véli, hogy azok az -é birtokjeles nevek szerkezeti átalakulása révén keletkeztek: a Vitézeké Vitézeké-féle névpárt hozza erre példaként (1993: 86). Az általam vizsgált névanyagban azonban egyetlen esetben sem jelenik meg a név szinonimapárjaként a birtokjeles alak, ami a névtípus elsődleges alakulásmódját jelzi. Mindez arra utal, hogy a -féle képzőszerü utótag e területen helynévformánsként müködve önmagában is alkalmas helynevek létrehozására.

A birtoklás mellett egyéb motivációk is szép számban előfordulnak az egyrészes határnevekben. Mindhárom térségben gyakorinak mondható a helyre jellemző növényvilág megjelölése, azonban legsürübben az ukrajnai területen találkozunk ilyen típusú nevekkel. Arányuk ebben a térségben kétszerese a romániai és háromszorosa a magyarországi területen mért értékeknek. A növénynévi lexéma az ide tartozó neveknek mintegy háromnegyedében -s képzővel áll. Ebből a szempontból területi eltérések nem jellemzők. Ezek köréből a következő neveket hozhatjuk példaként: Égeres, Rekettyés, Szilvás, Diós (ukrajnai terület); Akácos, Mogyorós, Szilas, Gesztenyés (romániai terület); Gyümölcsös, Meggyes, Csicsókás, Nyíres, Szőloós stb. (magyarországi terület). Kisebb arányban ugyan, de képző nélkül álló növénynévi lexémák is alkotnak egyrészes neveket: pl. Cser, Éger, Bükk, Tövis, Rekettye stb. A helyre jellemző állatvilág kifejezése is megjelenik egyrészes nevekben. Ezek aránya a növényzetre utaló nevekhez hasonlóan az ukrajnai térségben a legmagasabb. Döntő többségük ugyancsak $-s$ képzővel alakult (pl. Méhes, Csókás, Gólyás, Kígyós, Nadályos stb.), de képző nélkül álló nevek is adatolhatók (pl. Bagoly, Szúnyog, Limbuc, vö. limbuc 'bíbic' stb.). Egyrészes nevekben viszonylag gyakori az ott lévő épület, építmény megjelölése: Kutas, Akol, Gulyakút, Keresztnél stb.

A tulajdonságra utaló egyrészes nevek egyik leggazdagabb csoportját a terület méretét kifejező nevek alkotják (pl. Hosszú, Negyvenköblös, Egyholdas, Nyolcvékások, Tizenhárom, Héthektár stb.), de találunk a hely alakjára (Horgos, Hegyes, Kankó, Háromszegletes, Nadrág stb.), hangjára (Bömbölö, Zúgó, Dobogó, Bögető stb.), anyagára (Kövicses, Agyagos, Homokos stb.), egyéb tulajdonságára (Lágyos, Kenyeres, Aranyos, Ötkoronás, Ördöngős) stb. utaló neveket is.

A lokális viszony kifejezése is megjelenik egyrészes szerkezetekben. A táj természetföldrajzi jellegéből adódóan a vizsgált térségekben igen gyakoriak a víz közelében való fekvésre utaló nevek. A magyarországi térségben ez alkotja a lokális viszonyt jelölő nevek legnépesebb csoportját. Példaként említhetjük a Forrás, Erge, Csengeri-tó, Gémes-tó, Halastó, Fekete-víz, Köves-patak stb. elnevezéseket. Ezek a korábban vizek elnevezésére szolgáló helynevek metonimikus névalkotás eredményeképpen ma már határnevek elnevezéseként funkcionálnak. Hasonló a helyzet az egykori tanyanevek esetében is, ezek többsége ma már nem 
lakott helyet, hanem a helyén lévő megmüvelt területet jelöli (pl. Tobák tanyája, Szegedi-tanya, Szabó-tanya, Simon-tanya, Ilona-major stb.). Ez a névtípus a romániai térségben adatolható legnagyobb arányban. Tájrész közelében való fekvésre utalnak továbbá az Erdö mellett, Paládi-erdö alatt, Temetőnél, Zsidó-kert alatt típusú viszonyjelölö szerkezetek is.

5.2. Sajátosságjelölő névrészek tipikusan kétrészes szerkezetek előtagjaként jelentkeznek. Az alábbi diagram a sajátosságfunkció belső megoszlását mutatja a kétrészes nevekben.

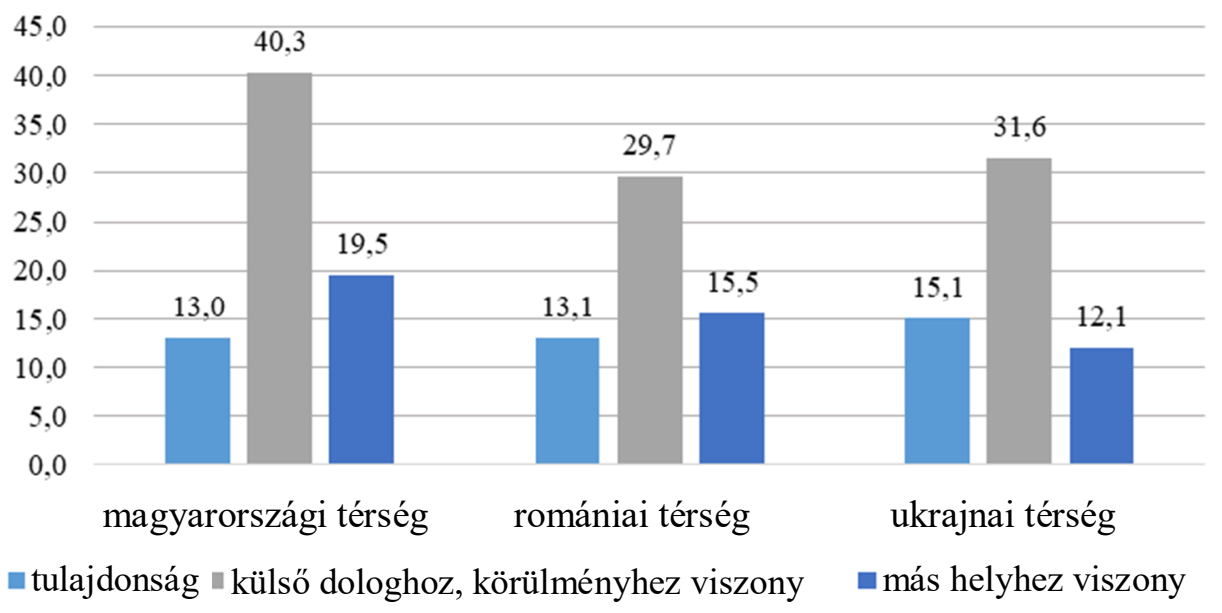

13. ábra. A sajátosságjelölö névrészek szemantikai megoszlása a kétrészes nevekben

A vizsgált térségekben a különböző névfunkciók megoszlása hasonló képet mutat. Az egyrészes nevekhez hasonlóan a legnépesebb csoportot a külső dologhoz, körülményhez való viszonyt megjelölő névrészek alkotják, a határon túli térségekben az összes névnek kevesebb mint egyharmada, a magyarországi területen pedig $40 \%$-a tartalmaz ilyen névrészt. Az e csoportba tartozó nevek közül itt is kiemelt kategóriának számít a hely birtokosára utaló nevek csoportja. A hely tulajdonosára utaló kétrészes nevek a magyarországi és ukrajnai térségben a határneveknek nagyjából egynegyedét teszik ki ( $27 \%$ és $23 \%)$, míg a romániai területen ezek aránya jóval alacsonyabb (17\%), ezen a területen ugyanis — ahogy azt az egyrészes nevek áttekintéséböl is láthattuk — a birtoklás kifejezése gyakran egyrészes nevekkel történik. A vizsgált településeken a kétrészes, birtoklást kifejező nevek gyakoriságát az alábbi térkép szemlélteti (lásd a 14. ábrát).

$\mathrm{Az}$ ukrajnai és magyarországi területen a települések legnagyobb részében egyértelmü, hogy a névhasználók a kétrészes névstruktúrákat részesítik előnyben a birtokviszony megjelölésére. A romániai térségben azonban e névszerkezetek a déli területen tünnek fel nagyobb arányban. Az északi, határ menti településeken 
a gyakoriságuk jellemzően $20 \%$ alatt marad, itt ugyanis az ilyen funkcióban álló egyrészes struktúrák nagyarányú előfordulása jellemző (lásd a 11. ábrát).

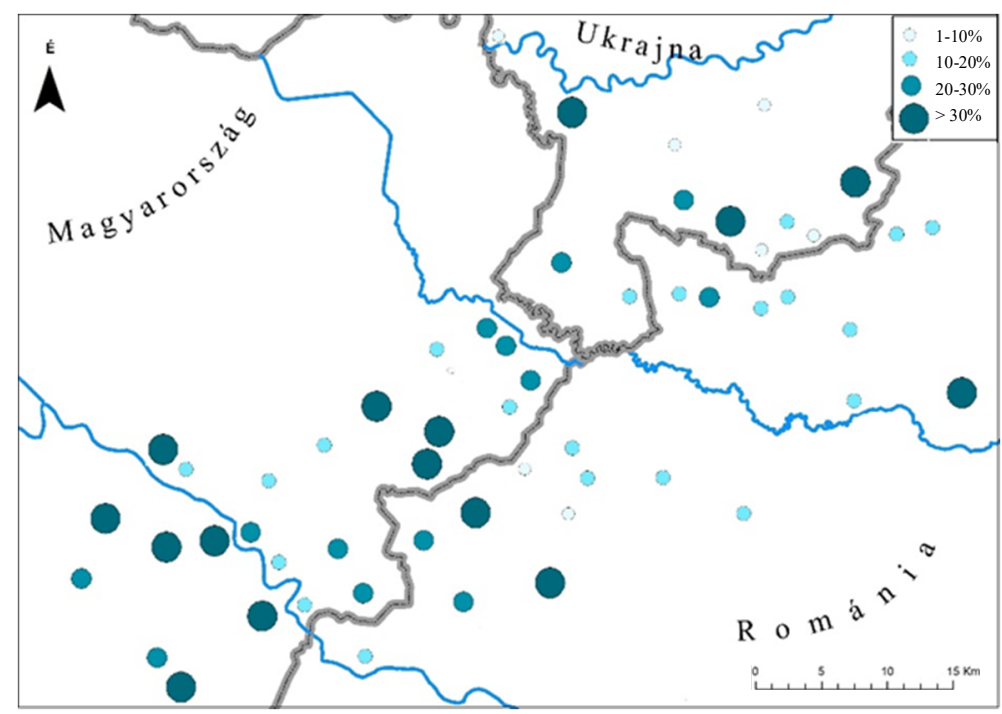

14. ábra. A birtokosra utaló kétrészes nevek elterjedése a vizsgált területen

Ha a kétrészes birtokosra utaló nevek nyelvi megformálását vizsgáljuk, jelentősebb eltérésekre bukkanhatunk. Kétrészes nevekben a birtoklás kifejezése történhet jelöletlen birtokos jelzős szerkezetek révén (pl. Bartha-rekesz, Lengyeltag, Gyene István-tag, Lukács-lapos, Kún-szeg stb.), illetve -a/-e, -ja/-je birtokos személyjel utótagon való használatával (pl. Horváthok tagja, Balla gorondja, Csürökné kertje, Zsiga táblája, Kotró sürüje, Kisasszonyok tagja stb.). A 15. ábra diagramja ezeknek a struktúráknak a megoszlását mutatja a vizsgált térségekben. Annak érdekében, hogy a tárgyalt névtípus nyelvi felépítésében mutatkozó területi eltéréseket szemléletesebben bemutathassam, ebben az esetben a százalékos gyakoriság kiszámításánál a birtokosra utaló kétrészes nevek számát tekintettem 100\%-nak. 


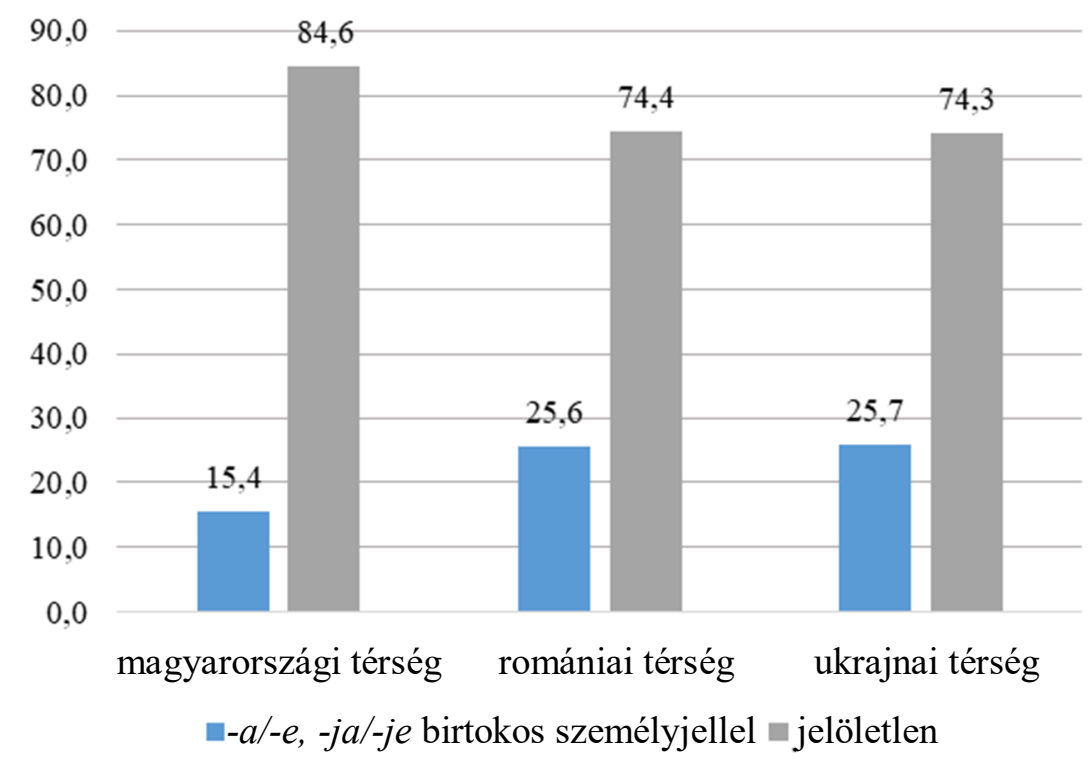

15. ábra. A birtoklás kifejezésére szolgáló struktúrák megoszlása a kétrészes nevekben

Noha mindhárom területen a jelöletlen struktúrák túlsúlya jellemzö, a határon túli térségekben az ide tartozó nevek egynegyedét jelölt szerkezetek alkotják. Ezek aránya a magyarországi területen jóval kevesebb, mindössze $15 \%$. Ez a területi eltérés az említett névtípus térképi megjelenítésekor is világosan megmutatkozik (lásd a 16. ábrát).

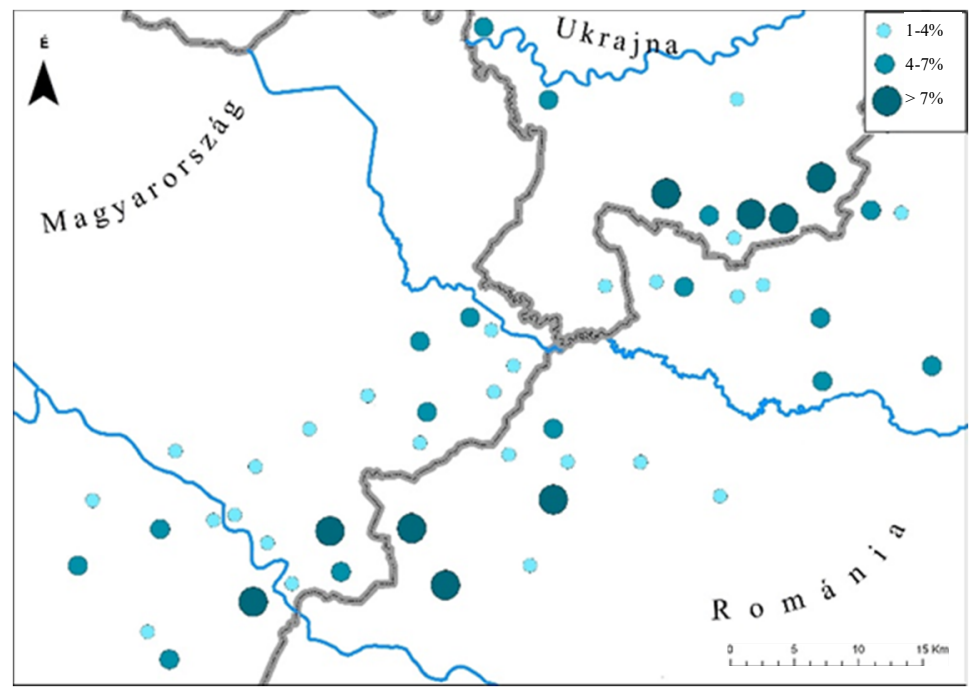

16. ábra. A birtoklást kétrészes jelölt struktúrával kifejezö nevek elterjedése 
A birtoklást kifejező struktúrák terén jelentkező területi eltéréseket DITRÓI ESZTER is vizsgálta a csíki régió, a Fehérgyarmati és a Veszprémi járás névrendszereinek bevonásával. Összevető vizsgálatából kiderült, hogy a birtokos személyjel használatának gyakorisága a nyelvterület keletibb területein nagyobb (2017: 60). Ez a tendencia az általam vizsgált térségekben valamelyest ugyancsak kirajzolódni látszik.

Figyelembe véve a korábbi megfigyelésünket is, miszerint az -é birtokjellel alakult egyrészes nevek a nyelvterület keleti része felé haladva válnak egyre gyakoribbá, talán nem megalapozatlan az a következtetés, hogy a birtoklás kifejezésében a jelöltség a keleti nyelvterület meghatározó vonása, míg a nyugati területeken inkább a jelöletlenség dominál. Ezt a feltételezést erősíti a birtokviszony kifejezésére szolgáló egy- és kétrészes jelölt struktúrák gyakoriságát együttesen ábrázoló térképlap (lásd a 17. ábrát).

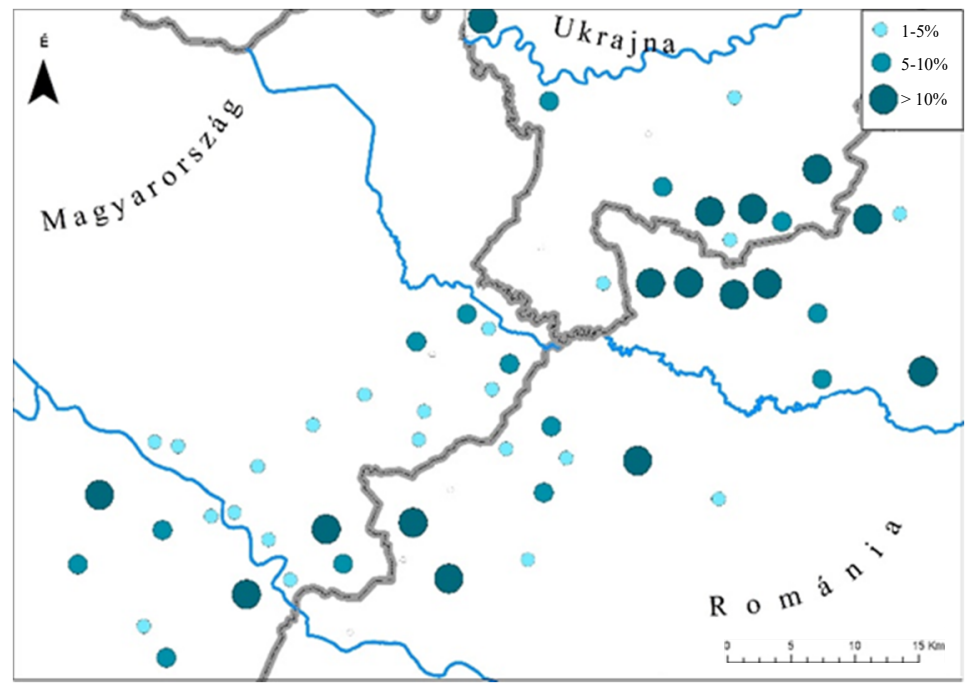

17. ábra. A birtoklást jelölt struktúrával kifejezö egy-és kétrészes nevek elterjedése a vizsgált területen

A térképen jól kirajzolódik, hogy a birtokviszonyt jelölt struktúrával kifejező nevek legmarkánsabban az ukrán-román országhatár mentén jelentkeznek. Meg kell azonban jegyeznünk, hogy míg a romániai oldalon mindez föként az -é birtokjel nagyarányú használatát jelenti, addig a határ ukrajnai oldalán a kétrészes struktúrák dominálnak.

A lokális viszonyt kifejező nevek lexikális morfológiai szerkezetét tekintve is területi eltérések mutatkoznak, melyek a birtoklást kifejező nevek esetében tapasztaltakkal némileg ellentétes képet mutatnak. Kétrészes nevekben a lokális viszony kifejezésére a jelöltség szempontjából többféle struktúra alkalmazható: az alaptagon jelölt birtokos személyjeles szerkezet (pl. Telek alja, Domb alja), a 
bővítményi tagon jelölt -i képzős szerkezet (pl. Géci-rét, Kerekes-tagi-legeló), valamint jelöletlen szerkezet (pl. Gögö-part, Belsö-kert). Az alábbi diagram ezek megoszlását mutatja a vizsgált térségekben (lásd a 18. ábrát).

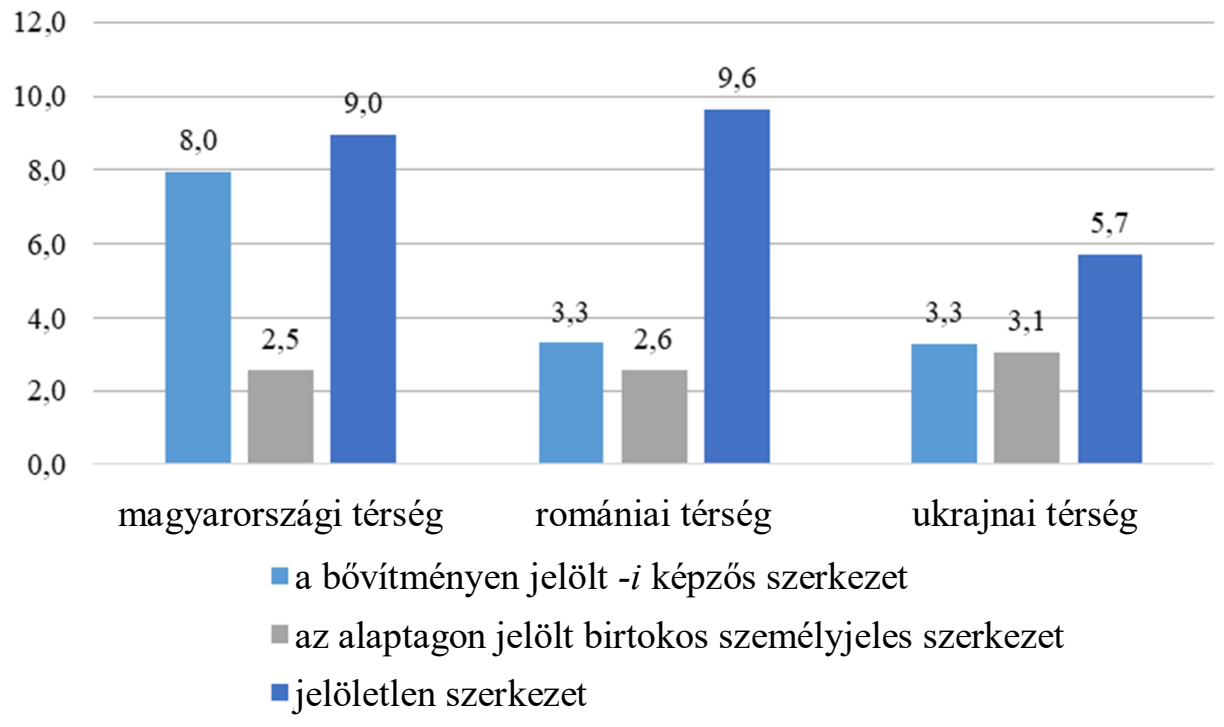

18. ábra. A hely más helyhez való viszonyát kifejezö szerkezetek megoszlása

Mindhárom területen a jelöletlen struktúrák alkotják a legnépesebb csoportot, ezzel szemben az alaptagon jelölt birtokos személyjeles szerkezetek gyakorisága valamennyi területen alacsony.

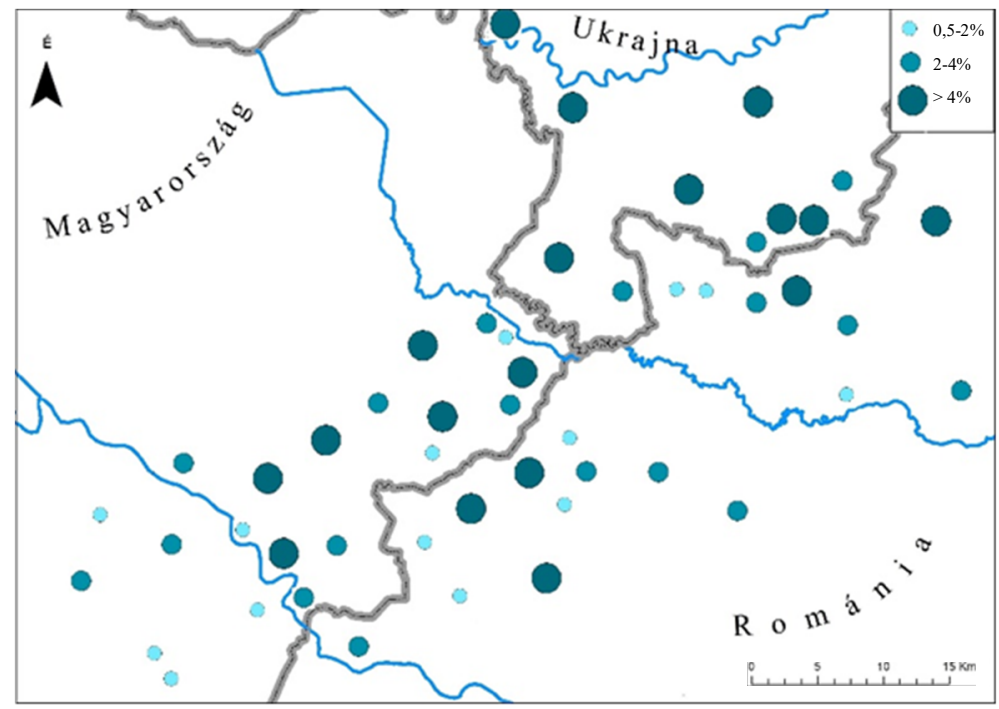

19. ábra. Az alaptagon jelölt birtokos személyjeles szerkezetek a lokális viszonyt jelölö kétrészes nevek körében 
Az alaptagon jelölt birtokos jelzős szerkezeteket tekintve jelentősebb területi eltérést az átlagértékek nem jeleznek, a névstruktúra gyakoriságát térképre vetítve azonban kivehető, hogy ezek felhasználása a romániai térségben kevésbé jellemzö. Noha itt is találkozunk kimagasló értéket mutató településekkel, a falvak nagy részében a névtípus kisebb gyakorisággal jelentkezik (lásd a 19. ábrát).

Jelentősebb különbség mutatkozik azonban a bővítményen jelölt $-i$ képzős szerkezetek terén. A magyarországi területen ezek aránya körülbelül két és félszerese a romániai és ukrajnai területen jellemző értékeknek (lásd a 20. ábrát).

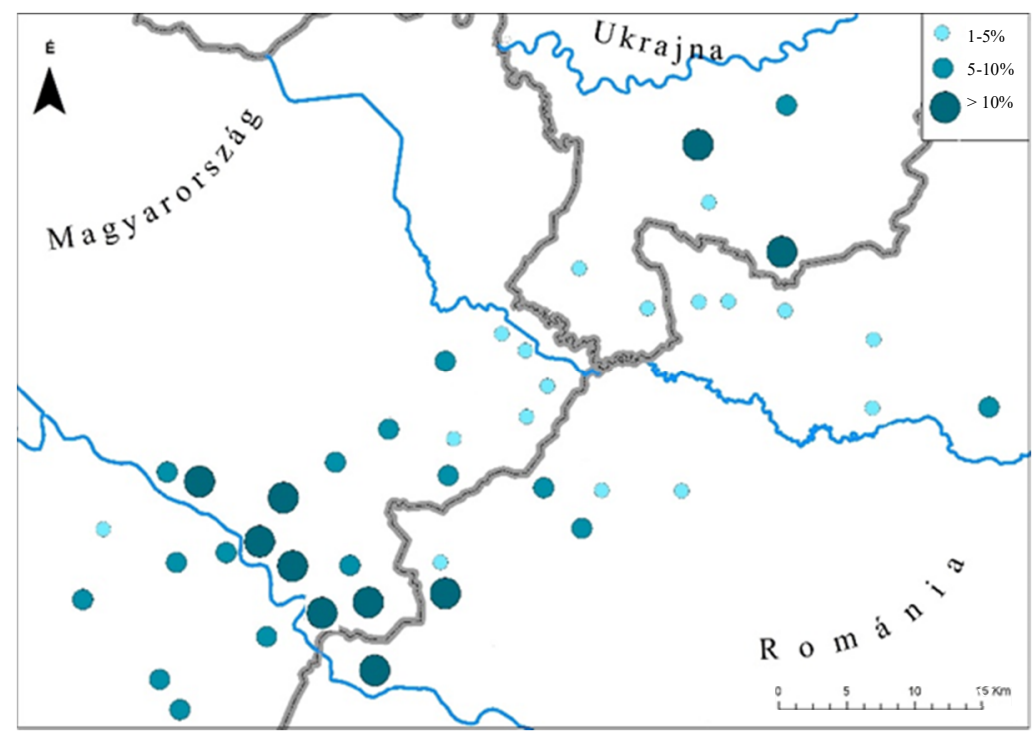

20. ábra. A lokális viszonyt az elötagon -i képzövel kifejezö szerkezetek elterjedése

A képzőelem elterjedésének térképes megjelenítése érdekes területi eltérésekre világít rá. Az - $i$ képző fő elterjedési területét talán nem is annyira az országhatárokhoz viszonyítva, hanem sokkal inkább egy folyó, a Szamos térségében jelölhetjük ki (noha a romániai területről igen kis számú Szamos menti település névanyagát vizsgáltam). Mind a magyarországi, mind a romániai oldalon az -i képző előfordulásának gyakorisága csak a Szamos menti települések esetében emelkedik 10\% fölé. Ezzel szemben a Túr menti térségben a névelem felhasználtsága jellemzően 5\% alatti mindhárom érintett ország területén.

Összevető vizsgálatom eredményei azt mutatják, hogy a helynévrendszerek területi eltérései egy viszonylag kis területen belül is megnyilvánulhatnak. A feltárt eltérések hátterében pedig joggal feltételezhetjük, hogy a névminták terjedésének gátat szabó száz éves országhatárnak is meghatározó szerepe lehet. 


\section{Irodalom}

BARTA VIKTÓRIA 2009. A kárpátaljai Gyula helynevei. Magyar Nyelvjárások 47: 213-224.

BURA LÁSZLó 2008. Szatmár megye helynevei 1-2. Csíkszereda, Státus Könyvkiadó.

DITRÓI ESZTER 2017. Helynévrendszerek modellalapú vizsgálata. A helynévminták összevető analizise statisztikai megközelitésben. A Magyar Névarchívum Kiadványai 40. Debrecen, Debreceni Egyetemi Kiadó.

FKnT. = BÁBA BARBARA-NEMES MAGDOLNA 2014. Magyar földrajzi köznevek tára. A Magyar Névarchívum Kiadványai 32. Debrecen. Debreceni Egyetemi Kiadó.

HANKUSZ ÉVA 2019a. Víznévrendszerek összevető vizsgálata. Magyar Nyelvjárások 57: 51-64.

HANKUSZ ÉVA 2019b. Határnevek összevető vizsgálata. Helynévtörténeti Tanulmányok 15: 149-162.

Hoffmann ISTVÁn 1993a. Helynevek nyelvi elemzése. Debrecen, Debreceni Egyetem Magyar Nyelvtudományi Tanszék. Második kiadás: Budapest, Tinta Kiadó, 2007.

HoFFMANN ISTVÁN 1993b. A helynevek szerkezeti változása. Hungarológia 3: 266278.

KÁLNÁSI ÁRPÁD-SEBESTYÉN ÁRPÁD 1993. A Csengeri járás földrajzi nevei. Debrecen, Debreceni Kossuth Lajos Tudományegyetem Magyar Nyelvtudományi Tanszéke.

Kiss Kálmán 2004. Egri község. Partiumi Füzetek 31. Nagyvárad, Partiumi és Bánsági Mủemlékvédő és Emlékhely Bizottság-Királyhágómelléki Református Egyházkerület-Nagyváradi Római Katolikus Püspökség.

KISS KÁLMÁN 2014. Túrterebes földrajzi neveinek története. Nagyvárad, Varadinum Script Kiadó.

KoCÁN BÉLA 2003. A földrajzi nevek vizsgálata a Nagyszölösi járás négy településén (Újaklin, Aklihegyen, Aklin, Nevetlenfalun). Kézirat. Szakdolgozat. Ungvár.

Póczos Rita 2010. Nyelvi érintkezés és a helynévrendszerek kölcsönhatása. A Magyar Névarchívum Kiadványai 18. Debrecen, Debreceni Egyetemi Kiadó.

SZILÁGYI-VARGA ZsUZSA 2015. A romániai Kisbábony helynevei. Magyar Nyelvjárások 53: 157-187.

ÚMTsz. = B. LÖRINCZY ÉVA. főszerk. 1979-2010. Új magyar tájszótár I-V. Budapest, Akadémiai Kiadó.

\section{A Comparative Study of Boundary Names in the Szatmár Region}

In my paper I study the regional differences in toponymic systems by means of the comparative analysis of the contemporary onomastic corpus of settlements located along the border. Earlier, similar studies explained the regional differences between name systems primarily with the effects of the geographical environment, 
migration, and the foreign language context (DITRÓI 2017). My paper examines the role of another factor, the impact of the border drawn in the wake of the Treaty of Trianon on the toponymic systems. My hypothesis in connection with this factor is that a long-lasting division, just as in language in general, reinforced separation in the toponymic systems as well. The 57 settlements examined in the paper are located in one block in the territory of three countries (Hungary, Romania, and the Ukraine), which provides an excellent opportunity for the examination of the above issue. I base my investigation on the toponym analysis model developed by ISTVÁN HOFFMANN (1993/2007), i.e., I complete the functional-semantic and lexical-morphological analysis of the names.

My studies focus not on the entirety of the name systems but only on boundary names as otherwise the results may reflect not the differences in the name models but that of the distribution of object types.

My comparative analysis has revealed numerous differences in the namegiving traditions in the areas separated close to one hundred years ago. The name structural overview has revealed a higher frequency of single-component names in the eastern areas beyond the border of Hungary. Such a trend has already been revealed by earlier studies. Another significant difference was revealed in terms of the use of structures expressing possession: in the Hungarian territory the large dominance of unmarked structures became visible, while beyond the border there is also a high number of unmarked structures. It is another major difference that in terms of expressing ownership, in the Romanian areas the use of singlecomponent, while in the Ukraine two-component marked structures is more frequent. The linguistic structure of names expressing a local feature shows an opposite trend compared to those seen in the case of names expressing ownership, as the frequency of marked structures in such a function is the highest in the territory of Hungary. 